\title{
Theological reflections on the ministerial challenges of the Dutch Reformed Church in Africa in the Orange Free State in post-apartheid South Africa
}

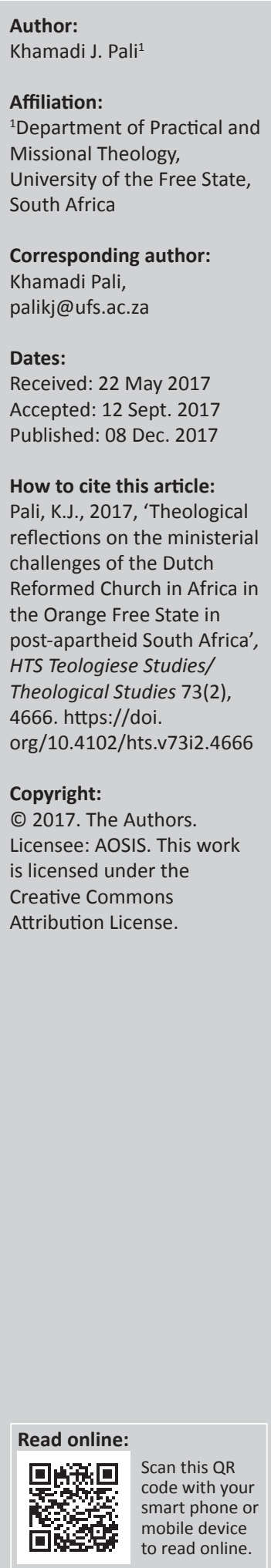

The Dutch Reformed Church in Africa (DRCA) is one of the Dutch Reformed family churches. It was established for the black Africans by the Dutch Reformed Church in the early 20th century. The contemporary situation in the DRCA is such that it is struggling with two issues: historical and contemporary ministry challenges. The challenges are growing at an alarming rate that soon the church may find itself in a crisis situation. This article uses the DRCA Orange Free State (OFS) as a case study. The research question is as follows: What is the theological reflection on the ministerial challenges of the DRCA OFS in the post-apartheid South Africa? The Practical Theological Interpretation theory of Osmer is used to analyse the situation in the DRCA OFS.

\section{Introduction}

The Dutch Reformed Church in Africa ${ }^{1}$ (DRCA) is one of the members of the Dutch Reformed family of Churches in South Africa together with the Dutch Reformed Church (DRC, for the Afrikaners), the Dutch Reformed Mission ${ }^{2}$ Church (DRMC, for the mixed race), and the Reformed Church in Africa (RCA, for the Indians) (DRCA OFS, ${ }^{3}$ Church Order 2003b:7, Article 2). The DRCA membership comprises of predominantly black Africans. The name DRCA was adopted after a merger of the four churches established for black Africans by the DRC on 7 May 1963 in Seeisoville, Kroonstad, in the Free State province of South Africa (DRCA OFS, Church Order 2003b:6, Preamble). Those churches are the DRMC ${ }^{4}$ in the OFS, ${ }^{5}$ the DRMC in Transvaal, ${ }^{6}$ the Dutch Reformed Bantu ${ }^{7}$ Church $^{8}$ in South Africa and the DRMC in Natal ${ }^{9}$ (DRCA OFS, Church Order 2003b:6, Preamble). According to Lebone (2002:277, 278), the purpose of uniting the DRCA churches in 1963, was to bring together black people, avoid alienation of the synods in different regions and start a process of integrating with other DRC mission churches from African countries.

According to Crafford (1982:149, 158, 173, 245, 564), prior to 1994, the DRCA had eight regional synods, namely the DRCA OFS (established on 9 March 1910 in Bloemfontein); the DRCA in Transvaal (established on 2 March 1932 in Johannesburg), which was later on 27 April 1964 divided into the DRCA in Northern Transvaal and the DRCA in Southern Transvaal regional synods; the DR Bantu Church in South Africa in Western Cape (established on 7 November 1951 in Molteno, Western Cape); the DRCA in Natal (established on 30 October 1952 in Ladysmith); the 1.Also known in Afrikaans as Nederduitse Gereformeerde Kerk in Afrika (NGKA) hereafter called the DRCA.

2.It was disbanded in 1994 when the DRCA regional synods merged with the DRMC regional synods to form the Uniting Reformed Church in Southern Africa (URCSA) on 14-17 April 1994 (URCSA 1994:413, 417). Later the DRCA OFS and DRCA Phororo regional synods withdrew (DRCA OFS 1995:11-14; 1999:9).

3.Orange Free State was one of the provinces during the apartheid era in South Africa, the new name is Free State province in South Africa. But the DRCA in the Free State province has not yet removed the name 'Orange', it is still used in its official documents, even at the time of writing this article.

4.DRMC, was also the name used for the churches established for the black Africans but after 1963, churches established for black Africans adopted the name DRCA. Later in this article, the name DRMC will be limited to the mixed race church and DRCA to the black Africans church as established by the DRC.

\section{Cf. footnote 2 .}

6.One of the provinces during the apartheid era in South Africa, it is now divided into the Gauteng, Limpopo and Mpumalanga provinces in South Africa.

7.Bantu was a name given to black South Africans during the apartheid era, and it is often assumed to be a derogatory concept for black Africans in South Africa.

8.This church was situated in the present Western Cape.

9.It was one of the provinces during apartheid South Africa, but now it has been merged with the former Zulu-tribe homeland and called KwaZulu-Natal. 
DRCA Phororo ${ }^{10}$ (established on 15 March 1966 in Mafikeng); the DRCA Eastern Cape ${ }^{11}$ (established in 1973), and the DRCA Transkei ${ }^{12}$ (established on 29 August 1978 in Umtata). In 1994 the DRMC (for mixed races) and the DRCA (for black Africans) united to form a new church known as Uniting Reformed Church in South Africa (URCSA General Synod 1994:413, 417). Later from the DRCA, the two regional synods, the DRCA OFS and the DRCA Phororo, decided to withdraw blaming the Moderamen of the DRCA General Synod of transgressing the church order in the process of unification (NG Kerk in Afrika s.a.; DRCA OFS 1995:11-14, 1999:9). In 2010, the DRCA Northern and Southern Transvaal combined regional Synod ${ }^{13}$ and, in 2015, the DRCA Eastern Cape regional synod ${ }^{14}$ were revived. In summary, after 1994 the DRCA has grown from two regional synods to four regional synods.

What contributed to this growth is not part of the discussion in this article, but suffice it to say it was because of the four factors to be mentioned in order of priority: Congregations that were previously members of the DRCA withdrew their membership from URCSA to re-join the DRCA. This withdrawal of some congregations from URCSA was due to some dissatisfaction with the new church (URCSA), longing for the return to the DRCA or congregation that follows its minister who decided to return to the DRCA. This growth of congregations that withdrew from URCSA contributed to an increase in the membership of the DRCA and the establishment of the two new synods as mentioned above. If it was not because of the refusal of the DRCA to recognise the legitimacy of the ministers from URCSA and the moratorium the DRCA had placed on the ministers from URCSA to be required a minimum of 18 months as members of the DRCA before accepted as ministers again, the majority of the DRCA regional synods would have been revived (DRCA OFS 2007:11). However, even though the DRCA may rejoice of those congregations withdrawing from URCSA, one should also be aware of the possibility that those congregations that withdrew from URCSA could in the future hesitate to engage in the unity process of the Dutch Reformed family of churches.

The second contributing factor to the growth of the DRCA post-1994 were baptised children of the members who later, at the age of sixteen years confessed their faith to become full members. The third contributing factor was the movement of members from one denomination to the other. The fourth and the last contributing factor was mission through evangelisation, farm and industrial ministry partially contributed to the growth of the DRCA especially

10.Phororo is a Tswana name for waterfali, and the synod of the DRCA Phororo is situated in what are now called North-West and Northern Cape provinces in South Africa.

11.The DRCA Eastern Cape is situated in the Eastern Cape Province of post-apartheid South Africa and includes Xhosa-tribe areas such as the former homelands of Transkei and Ciskei.

12.Former Xhosa homeland during apartheid era and it is situated in the southeastern region of South Africa.

13.Cf. the invitation letter from the Moderamen of the DRCA OFS (DRCA OFS 2010).

14.Cf. the invitation letter from the Moderamen of the DRCA OFS (DRCA OFS 2015). on the level of congregations. In summary, the growth of the DRCA was not essentially due to the mission work done, as mission work is declining and if mission work contributed anything to growth it would be to a limited extent (DRCA OFS 2007:109).

The DRCA OFS is one of the regional synods of the DRCA and in 2015 it had about 40 ministers with more than 100 congregations (DRCA OFS 2015:48). Some of these congregations are from other provinces like Gauteng, NorthWest and KwaZulu-Natal. More than half of the congregations in the DRCA OFS have no ministers, while one third of the present ministers are already at a retirement age. In 2015 there were three white missionaries who functioned as ministers in the DRCA OFS and they had the right to lead church council meetings as well as voting rights in the synod meetings of the DRCA OFS.

The recent reports from the assemblies of the DRCA OFS synod (DRCA OFS 2007:115; 2011:109, 133, 2015:19-24), indicate that there is a lack of commitment to mission, diaconate ministry and there are increasing conflicts amongst those in leadership. This kind of decline in the ministry seems to be the general trend in other regional synods of the DRCA (DRCA General Synod 2003a:61). In view of the increasing conflicts the Moderamen of the DRCA OFS raised the following question: How will the DRCA OFS witness to the world the good news of the Lord if it cannot practise them? (DRCA OFS 2015:32,33). In the light of the above the research question in this article is: What is the theological reflection on the ministerial challenges of the DRCA OFS in post-apartheid South Africa? The aim of this article is to theologically describe the ministerial challenges of the DRCA OFS in the post-apartheid South Africa.

This article will limit itself to the historical and contemporary challenges of the ministry within the DRCA OFS, and. leadership will not be the main focus of discussion in this as it needs its own attention if justice is to be done to it. This article is a product of a joint $\mathrm{PhD}^{15}$ project with empirical work which was submitted in 2016 (Pali 2016) to the University of the Free State, Bloemfontein and Vrije Universiteit, Amsterdam. The denomination used as a case study was the DRCA OFS. In that PhD project I used the Practical Theological Interpretation theory by Osmer (2008) to investigate and explain the situation in the congregations of the DRCA OFS. Further reading of how this theory was used and the details of empirical data consult Pali (2016: 27-30,39-55). This article uses the questions and their related tasks from Osmer (2008) and engages them on the level of academic research in order to understand and guide the process of research in terms of the situation of the DRCA OFS in the post-apartheid South Africa. The benefit of the Practical Theological Interpretation theory from Osmer (2008:10-11) in this article is that it helps to integrate theory and practice, empirical knowledge and theological knowledge and the context. Below is a brief discussion on how Osmer'theory church: A practical theological study of one denomination.' 
(2008:31-218) is used in the article to understand the situation of the DRCA OFS in the post-apartheid South Africa.

\section{What is going on?}

The first question according to Osmer (2008:31-78) is, what is going on? This question is related with the first task known as the descriptive empirical task. To achieve this task and respond appropriately to the question in the context of the DRCA OFS, the spirituality of presence, priestly listening and continuum of attending were applied. Spirituality of presence was engaged when various assemblies of the DRCA OFS were attended on the level of the church council, presbytery and synod meetings. Priestly listening was practised when the researcher sat in the DRCA OFS gatherings and shared the pain and frustrations of the leadership and members, in the process, sang and prayed with them for God to help the church regain its direction. Lastly, as contribution to continuum of attending, empirical research through mixed methodology was conducted in the congregations of the DRCA OFS (Pali 2016:39-56). Questionnaires from DRC church mirror were adapted and sent to the ministers and church council members in order to analyse the situation within the DRCA OFS. Individual and focus group interviews were conducted in eight congregations within the DRCA OFS. The following discussion of the results will focus on the historical challenges of the DRCA OFS as they culminated into contemporary challenges, and what impact they made on the internal and external ministry of the DRCA OFS.

\section{Historical challenges}

The DRCA OFS like any other church has a history which can help us to understand the essence of its present ministry. Early missionaries believed that a church is independent when it has reached the status of supporting itself financially, manage its own affairs and sustain its growth through mission work (Young 2007:119). However, concerning the DRCA OFS its independent status as mission church has dubious inferences and challenges. According to Crafford (1982:120) the DRCA OFS had the following historical challenges: growth towards independence, financial dependence, mission work and spiritual maturity. These historical challenges still prevail and in many instances have brought the independence status of the DRCA OFS into disrepute.

\section{Independence and financial dependence of the DRCA OFS}

Concerning the independence of African mission churches, Abah (2012:104, 105) argues that many African mission churches are eager to receive help and be dependent on the mother church. This has the consequence of sluggish growth in spiritual maturity especially concerning matters of ministry and finances thus making the mission church to be a beggarly church. This dependency on the mother church is common practice and encouraged by the leadership in the General synod of the DRCA (DRCA General Synod 2003a:57, $61,62)$. For example, the report of the commission on the ministry of the church to the General Synod of the DRCA
(DRCA General Synod 2003a:57, 61, 62) repeatedly encouraged members of the regional synods of the DRCA to seek financial and ministerial assistance from the nearest church council of the DRC. The above indicates the behaviour of the church that is used to receive and not understand the implication of being independent. It is no wonder that congregations in the DRCA, including DRCA OFS struggle to progress in the ministry.

The DRCA in general, including the DRCA OFS is officially an independent church with rights to make any decision it deems fit for its progress and ministry. However, most of its congregations are still dependent on the DRC Free State (FS) for financial assistance for their ministry and salaries of the minister which culminated in the failure of the DRCA OFS congregations to develop a sustainable financial model for its congregations. Kritzinger (2011:2) mentioned that in the Free State more than a million rand is spent by the DRC FS to fund the salaries and ministry of both the DRCA and URCSA. He is concerned about how this financial dependence impacts on the existence and future ministry of both churches.

For the DRCA OFS, this financial dependence is further perpetuated by the DRCA OFS Church Order (2003b:4) that encourages that congregations in the DRCA OFS should consult with the nearest DRC FS church council before they call a minister. Often, the reason is that the majority of the congregations in the DRCA OFS do not have money, and the salaries of their ministers are paid by the relevant church council in together with the nearest DRC FS or solely by the DRC FS. The consequence of this financial dependence on the DRC is that it inhibits the DRCA to be a missional church and encourages the relationship with resultant imbalance of power (Kritzinger 2011:127). For example, some members and ministers within the DRCA do think that it is the responsibility of the DRC to fund mission projects within the DRCA (Pali \& Verster 2013:242).

The other reason that perpetuates this dependency is that there are still some members of the DRCA OFS that still believe that the DRC is a state church and therefore it still receives money from the state, some of which should be used to fund the salaries of the ministers in the DRCA OFS. Even though the DRC was a state church for many years in the colonial and apartheid era (Cronjé 1982:12, 66, 70), it is no longer in the new post-apartheid South Africa. This means that in the future the privileges that the DRCA OFS used to get, for example, a subsidisation of their ministers' salary, free sites and free buildings, are things that will no longer come free but through hard labour. For example, during the apartheid era and some time post-1994, the DRC used to financially assist DRCA with erecting and maintaining buildings for its congregations. It is with regret to notice that since 1994 the DRCAOFS financial incomes were plummeting and the church may soon be declared bankrupt if it is not already so (DRCA OFS 2015:17; DRCA OFS 2017:3, 4). In the light of the above I conclude that the DRCA OFS is suffering from theological and financial dependency because of its 
habitual tendency to seek financial assistance and theological guidance from the DRC FS (Kritzinger 2011:118).

\section{Spiritual enrichment}

The challenge of spiritual enrichment is promoted by the influence of pietistic theology and narrow perception of the relations between gospel and culture. For many years, the influence of the white missionaries dominated the leadership in the DRCA OFS congregations, many of these white missionaries were influenced by the European pietistic theology and white supremacy (Dubow 2014:19; Elphick 2012:320). Bosch (2000:255) argues that the danger of pietistic theology is that it promotes escapism from this world and construction of absolute dualism between the sacred and the profane. According to Kritzinger (2013:10), for the Dutch Reformed family churches in South Africa pietistic theology encouraged separation of the soul and body, spirituality and political life, Sunday and weekday. Consequently this led to some members of the Dutch Reformed family churches becoming less critical and less active in matters that concern the transformation of society. For example, during the apartheid era the DRCA, including the DRCA OFS, was not sufficiently critical against the apartheid government (Kritzinger 2013:2, 9, 10; Masuku 2014:159). Presently, the situation still prevails as the DRCA OFS is mostly silent in matters that relate to the state and political situation of South Africa, and if it reacts it is privately through its commissions' reports (DRCA General Synod 2003a:116; DRCA OFS Synod 2011:153-156).

The other factor which relates inextricably to spiritual maturity is gospel and culture as perpetuated by white supremacy over African culture. The influence of white supremacy as practised by many white missionaries led to the distorted interpretation of the relationship of the gospel and African culture (Lartey 2013:xii). The consequence of the practise of this white supremacy regrettably devaluated African culture, ruined the black Africans' dignity, as well as their political and racial aspirations (De Jong 2001: 51-65; Gordon 2002:12; Kgatla \& Magwira 2015:320). This devaluation of African culture by white missionaries disconnected most Africans from their cultural heritage, thus acculturating most Africans. The consequence was that most Africans suffered from human indignity which led to psychological deprivation and low self-esteem. Furthermore, to perpetuate this white supremacy over black Africans, religion and racist ideologies were used to justify inequalities, exploitation and distract the oppressed indigenous African people from fighting against injustices in the structures of society and focus on matters that concerned spiritual development like prayer, singing and reading the Bible (Kgatla \& Magwira 2015:320).

No one should dictate how the other should respond to the demands of the gospel about his or her culture but rather we could help the other to understand their position and identity in God and the demands of the gospel so that they can respond appropriately. The DRCA OFS, seems to have been dictated to by the white missionaries on how to respond to the demands of the gospel in relation to African cultural practices (Thuto ya Bokreste 1987:205, 206). The majority of its leadership seems to not have applied its intellectual aptitude and spiritual discernment on many African cultural practices which the church's theological practices and documents demonises. On forbidding some African cultural practices the DRCA OFS did not provide a solution for the vacuum created and how to adequately engage temptations that would arise from a need to perform some of those forbidden cultural practices.

The consequence of this failure was ambiguous spiritual life practices of most of the members of the DRCA OFS. For example, the DRCA OFS has an ambiguous view on the traditional initiation school. Thuto ya Bokreste (1987:206), the basic spiritual formation book used by the DRCA OFS, states that the traditional initiation school is not Christian and those who participate in it should be disciplined. The recent position in the DRCA OFS Synods (2007:129, 130; 2011:154) reported that those who practise this should be left alone. As this is part of African culture, it will continue to be practised and affect the church in many ways. As observed, some of the ministers and members of the DRCA OFS partake in the practises and leadership within traditional initiation schools. The DRCA OFS should review its theological point of view and examine the possibilities of Christianising the practice of traditional initiation schools. If the above suggestions succeed, it will reduce the confusion and enrich the practice of African culture and ministry amongst African Christians.

\section{Mission}

Concerning participation in mission by African churches, Vumisa (2012:123) says that white missionaries did not pass the vision for missions to the church in Africa. This created the impression that mission is the task of foreigners or white people and the church is for the natives. Though contemporary studies view mission as multi-dimensional (Bosch 2000:511, 512; Schoeman 2015:365), the practice of mission in the DRCA OFS is still narrow as it is separated from the diaconal ministry (DRCA OFS, Church order 2003b, Article 46, 47). Historically, mission in the DRCA OFS ${ }^{16}$ was funded and dominated by the white missionaries who enlisted the services of the catechists and black African ministers. This does not necessarily deny the initiatives of the congregations of the DRCA OFS in doing mission within their immediate environment (Thuto ya Bokreste 1987:189).

However, the influence and the legacy of the white supremacy is still visible among some individuals in the DRCA OFS congregations who still have this narrow notion of mission as evangelisation of the black people by the white people and as the responsibility of the DRC to fund mission projects (Pali \& Verster 2013:227-253). Recent reports on mission within the congregations of the DRCA OFS (2007:109; 2010:19; 2011:118) in relation to local and international contexts indicate that mission practice is declining and may soon collapse. in the FS and Lesotho with more than a million rand (DRCA OFS 1975:69) 
Furthermore, according to Pali (2016:334) mission in the congregations of the DRCA OFS is understood as a project not as an identity of the congregation. Does this mean it is true that the DRC FS did not pass a vision for mission to its family churches? The answer is complex, on one side I can say yes. This is in the context in which the dependency syndrome of the DRCA OFS has made it to suffer from low self-esteem and the presence of the DRC FS creates an aura of the mother and daughter relationship. This means that the majority of the congregations of the DRCA OFS expect the DRC FS to lead and fund a lot of mission projects. On the other hand, I can say no and attribute the failure in mission and community projects to the weakness of DRCA OFS to learn and be creative in the ministry.

\section{Contemporary challenges}

The contemporary situation in the DRCA OFS indicates that the old historical ministerial challenges as discussed above were not resolved, they have now culminated into contemporary challenges. This means independence, financial dependence, spiritual maturity, and mission work are still lagging within the ministry of the DRCA OFS. To understand the contemporary situation of the DRCA OFS I divide its history into two periods. One period is from its birth in 1910 towards 1994 and the other one is from 1994 to the present.

\section{Period of 1910-1994}

This period, despite the inability to deeply engage historical challenges, was a period of growth and prosperity in relation to the DRCA OFS infrastructure. Accolades should be given to the catechists, evangelists, ministers and white missionaries for their hard labour in mission (Odendaal 1956:63). Again, one should also note that often the control over the ministry work was largely in the hands of the white missionaries and the DRC FS that funded the ministry and offered leadership (Odendaal 1956:64, 65). This means during this period of the DRCA OFS it fully received all the support it needed in its development as a daughter church to the DRC FS and the influence of the white missionaries was dominant (DRCA OFS 1975:64). During this period, the DRCA OFS with the financial support of the DRC FS and influential leadership of the white missionaries from the DRC FS managed to perform successfully many community projects and mission among the black community. Some of them were Stofberg Memorial School, Strydom Education College for the training of teachers and ministers, Lehlasedi as church newspaper, a bookshop for selling church religious and administration books, press shop, Barend van Rensburg orphanage, and a church building as offices for the church in Bloemfontein, industrial mission on the gold field mines in the Free State and mission in the industrial area of Sasolburg (Cronjé 1982:65, 66; Odendaal 1956:64, 65).

\section{Post-1994 to the present}

Post-1994 is a period of decline in the ministry of the DRCA OFS. In 1994, all the DRCA regional synods united with the
DRMC (for the mixed race) to form URCSA. Later, the DRCA OFS and DRCA Phororo regional synods withdrew from the unity process to form a new church, URCSA. This led to litigation over properties and status of the DRCA (DRCA OFS 1999:12). The litigation cost both churches, that is the two DRCA regional synods and URCSA, to incur huge financial debt. On the grass-roots level members of the same congregation and family fought over ownership of the property of the church. On the level of leadership, that is, between the ministers of URCSA and the DRCA there was some incidental physical conflict, and regular litigation against each other. In retaliation the DRCA general synod sanctioned all ministers who crossed over to URCSA by placing a moratorium demanding that all those ministers from URCSA, before they could be accepted as ministers by the DRCA needed to be members first for a minimum period of 18 months (DRCA OFS 2007:11). In 2015 the DRCA OFS regional synod announced that through the mediation of the DRC, a settlement had been reached between URCSA and the DRCA regional synods (DRCA OFS 2015:25-31). This happened through the financial compensation of those congregations that had lost their buildings and a peace agreement between the two churches to reconcile and work together.

Post-1994 the DRCA, especially in the Free State, spent most of its energy and money for survival against the huge schism it suffered. Less time and resources were expended on the issues that concerned its core ministry. Consequently this led to the decline of ministry in the congregations, on presbytery and synodical level (DRCA General synod 2003a:61). The decline manifested itself in the low performance of mission, ambiguous relationship between gospel and culture and lack of commitment to engage historical challenges. Further decline in the ministry showed itself in community projects, societal engagement and leadership (Pali 2016:83, 120). As far as community projects were concerned, the DRCA OFS feeding scheme tops the list of the community projects done by the congregations of the DRCA OFS and many congregations operated on the level of social relief whereby the immediate needs like food and clothing for the poor were met (Pali 2016:107). To the DRCA OFS $(2007: 115 ; 2011: 133)$ the societal engagement is part of diaconate ministry but due to non-submission of reports the DRCA OFS is uncertain of extent to which its congregations are involved in societal engagement. This is the situation even after efforts to train and invite congregations to use the help of the DRCA OFS Synodical office or the DRC FS (DRCA OFS). However, according to the empirical report of Pali (2016:97) poverty, HIV and AIDS top the list as major societal challenges and regrettably most congregations do not have any strategy put in place to alleviate them.

\section{Why is this going on?}

Before responding to this question: 'Why is this going on?', it must be noted that this is the second question from Osmer's theory (2008:79-128). The question is related to the second task of Osmer's (2008:79) interpretive task. Osmer (2008:82) 
states that the interpretive task requires application of sage wisdom. This sage wisdom requires the interplay of three key characteristics. Firstly thoughtfulness, which implies quality reflection about the questions life throws at a deeply committed leader, especially when experiences are not enough for an in-depth understanding of the situation. In this article thoughtfulness is about the critical reflection on why the ministry in the DRCA OFS is declining. Secondly, theoretical interpretation denotes the ability to draw on theories of art and sciences in order to understand and respond to particular episodes. Third and lastly is wise judgement, the capacity to interpret episodes, situations and contexts that are mainly related to the context of African society and its churches. In this article I will also give my authentic judgement on the impact of the history and legacy of white imperialism in the context of the DRCA OFS in particular. Understanding what happened in the past and why it happened will facilitate healing and create opportunities for the beginning of a new narrative of wellness and will challenge one to participate in the changing of the direction of the end of the story (Duran 2014:xiii, xv). The following discussion on why the ministry is declining in the DRCA OFS, will not focus explicitly on the role of leadership because of limited space and time in this article.

\section{The legacy of white imperialism}

South Africa suffered three oppressive onslaughts they are, slavery, colonialism and apartheid and all amounted to white imperialism in a different form. In this study I prefer to talk about the legacy of white imperialism because I believe the system of apartheid was just the climax of white imperialistic forces such as slavery and colonialism (Coetzee \& Conradie 2010:119; Nimako \& Willemsen 2011:152). The DRCA OFS (2003:27) specifically survived through all these white imperialists' forces. According to Kane (1978:247), white imperialism had three forms: the first one is political, represented by the colonist who may be a political leader of a colonial country or imperial government. The colonist aims at external ordering through legislation and domination which leads to psychological and cultural consequences (Saayman 1991:24). The evidence of this in South Africa was legislation of the Group Areas Act and Land Act during the apartheid era whereby black people were classified as thirdclass citizens and denied ownership of land within the Republic of South Africa. The consequence of this on the DRCA OFS was that its members who were predominantly black people and were viewed as third-class citizens and not allowed to own land within the boundaries of the Republic of South Africa. Hence, the title deeds of many of the buildings of the DRCA OFS have been and some of them are still in the hands of the DRC FS.

The second form of the white imperialist force was economic, represented by the merchant who in radical terms can be called the capitalist. The oppression here was effected through forced labour, and denial of black people to partake in certain careers. This led to practices of enforced labour, chattel slavery and material poverty. In the DRCA OFS this was manifested by the majority of its members who were poor, the majority of those employed was for menial jobs, and could therefore not afford to pay their minister.

The third form of white imperialism is a cultural one represented by the missionary who colonised the mind and changed the whole system of belief and practice (Saayman 1991:24). Most of the white missionaries used the Christian religion to influence the thinking and the belief system of Africans (Van der Walt 2003:24). In the process, some white missionaries abused the Christian religion to devalue African cultural practices without applying the critical mind and providing an adequate alternative replacement for the rejection of some African cultural practices. This created spiritual and cultural confusion for many Africans (Buntu's 2013:2). This confusion was realised when the DRCA OFS adopted an ambiguous viewpoint on traditional initiation schools and lacked the creativity to respond to the gospel and the guidance of the Holy Spirit.

The ramification of white imperialism exposed black Africans to a worst form of inhuman treatment which stripped black Africans of their political, economic and cultural development, particularly in South Africa. Moreover, it must be noted that white imperialism adversely affected all the races in South Africa. Its legacy should be re-examined for white people as the former oppressors and black people as victims of the previous oppressive system that occurred prior to 1994 in South Africa which made both black and white South Africans suffer from existential insecurity (Du Preez 2013:8; Gumede 2012:128). For example, both black and white people suffer from existential insecurity which is manifested in fear and mistrust of each other. Black people have fear of white manipulation and victimisation; and, white people have a fear of the redistribution of wealth, poor standards and punitive taxation (Mbigi \& Maree 1995:57, 58). In the context of the DRCA OFS it is very complicated to identify fear and mistrust between both white missionaries and ministers of the DRCA OFS who are predominantly black Africans. However, I observed during some assemblies and interaction with the DRCA OFS ministers especially in 2017 a mistrust of white missionaries by some young ministers in the DRCA OFS. This was because of some interference in leadership activities and decisions made by some of the few remaining white missionaries.

\section{Mission policy of the DRC}

Mohlamme and Qakisa (1992:231), Lubbe (2001:17), Van der Watt $(2010: 2,3)$ and Dubow (2014:27) agree that during the apartheid era, mission within the DRC, including the DRC FS was driven by the ideology of apartheid that encouraged the paternalistic approach and the segregation of churches based on race. The racially influenced mission policy of the DRC had implications within and far beyond the ecclesiastical realms. Ecclesiastically it affected the process of unification within the Dutch Reformed family churches, and politically promoted the Afrikaner Nationalist policy of separate development beyond the church. 
The DRC mission policy and white imperialism had some negative consequences on the early development of the DRCA in the Free State. The DRCA OFS was gradually established in the late 19th century (Cronjé 1982:63), during the demise of official practice of slavery and officiation of colonialism, characterised by racial discrimination, paternalism, and capitalism and the gradual development of apartheid. During the early 20th century, the politics of Black Nationalism was growing in intensity. As a result, there were many uprisings against white dominance in politics and churches, and practice of racial discrimination.

According to Odendaal (1970:485-521), the following factors were the challenges the missionaries faced in the process of establishing the DRCA OFS: tension between culture and the gospel that often led to the practice of syncretistic Christianity; involvement of missionaries with the oppressive political system; and the impact of world wars caused many black people to lose trust in, and oppose white missionaries. The association of Christianity with westernisation led to an assumption of superiority of European culture through civilisation, Christianisation and dress (Odendaal 1970:485521). The other factor was the Ethiopian movement that influenced black people to be independent of white influence and establish their own independent churches. According to Kalu (2006:581), the Ethiopian movement can be traced to the African Americans in 1850-1925 in response to the global enslavement of Africans. It called for the freedom of Africans from religious and political dominance by the Europeans. Black Nationalism fuelled this quest for African ownership, identity, self-respect and opportunity to nurture Africa back to its glory. The last factor is the schism within the congregations that was influenced by the Ethiopian movement and a desire to affirm black leadership. After a long struggle and a series of consultations, the DRMC was established in 1910 (Odendaal 1970:551).

However, even after the establishment of the separate black church (DRCA OFS), the white missionaries were still reluctant about the readiness of this mission church to run its affairs (Elphick 2012:225). The arguments lodged were that the mission church was neither ready to run its affairs, nor financially strong, nor fully developed to be independent, nor ecclesiastically organised (Odendaal 1970:551). As a result, the mission church DRCA OFS was subjected to a period of guardianship whereby its synod, constitution, articles and laws were subjected to the DRC FS approvals, and the officials of the DRC FS had the right to attend DRCA OFS synodical meetings (Crafford 1982:175).

In summary, the above discussion indicates that the DRC apartheid mission policy and white imperialism had a devastating impact on the psychological and spiritual development of the DRCA in general. For example, the racist paternalism of missionaries ruined the Africans' dignity, as well as their political and racial aspirations (De Jong 2001:5165). It also made the DRCA OFS suffer from a dependency syndrome as it was used to receiving funds and ministerial assistance and the DRC FS was too ready to assist in many aspects of the ministry like mission, community projects and financial assistance to the salaries of some of the ministers in the DRCA OFS. Hence, the DRCA OFS as one of the mission churches in Africa still has the challenge of a declining mission and diaconial ministry, distorted interpretation of the gospel and culture relationship, and lack of practice of indigenous Christianity (DRCA OFS 2007:109; 2015:15-29,119; Pali 2016:105). However, I acknowledge that there were sincere and honest white missionaries in the DRCA, and DRCA OFS in particular, who resisted the apartheid mission policy of the DRC. Regrettably, the good work done by these sincere and honest missionaries from the DRC FS is overshadowed by the consequences of the legacy of white imperialism and the weakness in the ministry of the DRCA OFS. If no appropriate solution is found to the declining ministerial situation of the DRCA OFS, a schism and continuous violent conflict within the structures of the DRCA OFS might develop.

\section{What ought to be going on?}

The third question from Osmer's (2008:129-173) theory is the following: 'What ought to be going on?' This question is related to the third task known as Osmer's (2008:129) normative task. The normative task is practised within the context of a process of prophetic discernment, which involves the practice of making good judgements and applying theological and ethical interpretation to a situation with the aim of engaging in good practice and to do the will of God. Good judgement accompanied with correct theological and ethical interpretation may lead to appropriate direction of congregational ministry and leadership practice. On this point, the hypothesis of this study is, that because of the intensity of the legacy of white imperialism and the weakness of the DRCA OFS to read the signs of time and discern the guidance of the Holy Spirit, it is undergoing a slow death. The solution to such challenges for the DRCA OFS, various scholars suggest are, that it should start from engaging the inner being of the human being, whereby self-consciousness of the mind, conversion, spiritual awakening of the human spirit and seeking the God's kingdom are implied (Buntu 2013:2; Du Toit 2009:22; Sandford \& Sandford 1982:5, 8; Van der Walt 2003:115). The appropriate decision to help the DRCA OFS out of this slow death process depends on its capacity to engage in spiritual discernment about divine guidance amid circumstances of its own ministry. The spiritual discernment happens by listening to the Word and critical reflection from the missional, theological and spiritual conscience in order to appropriately review any ministerial activity that is inappropriate and support ministerial activities that promote values of the kingdom of God.

\section{Prophetic judgement}

The solution to the above-mentioned challenges for the DRCA OFS are complex and not something that can happen overnight. However, the prophetic judgement on the present situation in the DRCA OFS indicates that it is undergoing a slow death and if anything constructive is not done it will 
eventually die or disintegrate. It is possible for the DRCA OFS to transform from its present situation to a church that is active, transformative, visionary and missional in its ministry. From scripture we learn that it is possible that God can transform an already dying and dysfunctional institution and make it alive and active. For example in Ezekiel 37:1-14 it is God through his Word and Spirit who initiated a process of transformation of the dried bones which transformed into a lively and active nation. Knowledge of the Word of God followed by commitment to engage in concrete acts of faith are a prerequisite for the beginning of the process of deep change. For example, in 2 Kings 22-23 and 2 Chronicles 17:112; 34:29-33 it was after the discovery of the book of Law in the temple of the Lord and its study that the leadership in Judah repented and a process of spiritual and social transformation was implemented.

To achieve this spiritual and social transformation the DRCA OFS needs to review its relationship with the Triune God and mission. This will help members of the DRCA OFS to grow from their inner being to the external relationships and behaviour. For example, Hunter (1989:119) argues that believers need to grow and the goal of growth should target the inner being which when matured makes one authentic disciple of Christ. Hunter (1989:120, 121) argues that this growth has four parts: growing up in grace and knowledge which involves growing in relationship with God and knowledge of the Word of God. Growing together which implies striving for a quality relationship characterised by love of one another, forgiving, accepting the other irrespective of the ethnicity, origin and status. The next part is growing out whereby one establishes a relationship and challenges the status quo, and injustices in the societal structures for the purpose of allowing shalom and justice of God to prevail. The last part is growing more whereby church planting occurs because of a growing membership and a need arises to organise believers to interact and serve God.

According to empirical work by Pali (2016:141-145), growth in the above-mentioned areas is a gradually mounting challenge in the congregations of the DRCA OFS. This means the DRCA OFS is facing a growing challenge from its internal and external ministry. For example, the majority of the participants in the empirical study of Pali (2016:141-145) mentioned that concerning growth in personal relationships and worship of God within the congregations of the DRCA OFS, not much is done except the practice of worship service, therefore, they requested some help in this regard. Concerning growth in the knowledge of the Word of God, it was discovered that preaching and singing is more dominant in many congregations of the DRCA OFS, rather than the intense study of the Word of God. On the issue of growing together, the study revealed that the fellowship of believers is emphasised and practised during worship services and at ward meetings and participants reiterated that more needs to be done in this regard. For example, there are growing conflicts among ministers themselves, ministers and congregations, as well as members of the congregations (DRCA OFS 2007:9; 2011:25; 2015:20-23). These conflicts hinder the practice of love, acceptance of each other and forgiveness among believers in the DRCA OFS. As far as reaching out into the world, the DRCA OFS ministry regarding societal engagements is declining, because community projects like feeding schemes and giving clothes to the poor, are mainly for social relief purposes, and social challenges like poverty and HIV and/or AIDS and many congregations do not have any strategy in place to reduce their negative impact on society (Pali 2016:106). As for increased growth, it was mentioned above that growth in the DRCA OFS is not due to intense missional practice but to baptised members who confessed their faith to become full members, members who move from one denomination to the other, and congregations returning from URCSA.

\section{How might we respond?}

The last question is: 'How might we respond to the situation of the DRCA OFS?' This question is related to the fourth task of Osmer's (2008:175-218) pragmatic task. It is hoped that solutions to the challenges faced by the mainline churches like the DRCAOFS, will be subjected to an analytical discussion of its vision, situation and strategy for implementing the changes. Leadership is essential in the implementation of changes (Hendriks 2004:197). As a result, this is where guidance by leadership is crucial. For leadership to guide a congregation towards new directions it will need to discern the contemporary situation of the congregation, the history and have a vision empowered by the power of the Holy Spirit. A minister as interpretive guide must help members understand the present situation, their identity and their task in shaping the new course for the congregations. In the next section, a possible holistic solution for the declining ministry in the DRCA OFS is suggested.

\section{A need for an appropriate change in ministry}

Congregations need to constantly review their ministry in order to assess if there is any need for change in line with the Word of God. However, Shawchuck and Heuser (1993:158, $165,167)$ argue that change in a congregational ministry can bring about growth or decline depending on how congregations respond to that needed change. They further say that there is no need for a change in congregational ministry to bring about a decline. Instead, change in congregational ministry must create new opportunities for new enterprise and sustain the congregations through difficult times in its history. But the majority of the congregations in Africa are trapped in a mentality and ministry framework that has difficulty to appropriate a necessary change to a congregational ministry, hence, there are many congregations that are stagnant and dying a slow death (Hendriks 2004:35; Shawchuck \& Heuser 1993:158).

But what kind of appropriate change is necessary for congregations that struggle with internal and external ministry like those in the DRCA OFS? Hendriks (2004:35) suggests a need for transformation towards a ministry that would make congregations to be missional and grow towards 
spiritual maturity, that discern independently the guidance of the Triune missional God and become involved in making the kingdom principles important. This could be helpful to the DRCA OFS which is struggling with independent theological reflection on some cultural practices and lost integrity because of poor relations and conflicts. Bragg (1987:39) defines transformation as taking what is and turning it into what it could and should be. For example, like a caterpillar that turns into a beautiful butterfly. Osmer (2008:202) states that transformation can be evolutionary or radical. Evolutionary transformation is creating small changes over a long period of time and those changes are mostly incremental and continuous with the past. Radical transformation usually is over a short period of time, disturbs the equilibrium in the congregation and brings about discontinuous and deep change in the structure, function, and operating procedure of the congregation. It must be noted that transformation is risky and it may give rise to conflicts, crisis and resistance (Hendriks 2004:38; Osmer $2008: 196,198)$. Hence, it must be guided by love and focus on the mission of the Triune God and the intention to achieve what God intends us to be. For the situation of the DRCA OFS the kind of change needed is urgent and radical transformation of its ministry and leadership practices to transform its missional practices, engage legacy of white imperialism and dependency on the DRC.

\section{Missional understanding}

It has been established that the African church has a tendency not to be keen on the effective missionary role of the church and funding of mission (Kekana 2012:73). This was proven in the above discussion on the poor mission practice and financial dependency of the DRCA OFS on the DRC. When a congregation has a clear understanding of the mission of the Triune God, there is potential that the being, practices, and actions of that congregation will be clear. The mission of the Triune God is about reconciling humanity with the Triune God (Van der Borght 2005:239). It is at the very heart of the Triune God and work on earth (Khauoe 2009:14, 15). Mission of the Triune God is delegated to the congregation as the working and identity of a congregation. Mission of the Triune God is the direction and calling of the congregation (Schoeman 2015:365). Mission of the Triune God as a calling and the mandate of the congregation involves witnessing about the coming of the kingdom of God (Guder 2000:66). This witnessing about the mission of the Triune God entails actions such as proclamation, fellowship, and service to society. This witnessing is spiritual and necessitates societal engagement (Bouwers-Du Toit 2010:263). The spiritual aspect involves the authentic proclamation of the Word of God within and beyond the borders of the congregation. The societal engagement implies the responsible involvement in the transformation of human and societal institutions in the world. To have an effective missional practice of a congregation, the missional practice has to target the transformation of the inner person and external behaviour of an individual in his or her personal and public life. This kind of transformation which targets the inner person first could help engage with human spiritual, psychological and moral problems that influence the effective of social structures. Hence, in dealing with the legacy of white imperialism, the transformation of the inner person, like the mind, emotions and spirit, if prioritised could facilitate effective transformation of the social structures (Du Toit 2009:22). If in congregational context transformation of the inner person does not happen, then all the programms and congregational changes will just evaporate (Roxburgh \& Romanuk 2006:63). However, in the DRCA OFS there needs to be a shift from a declining missional practice and an understanding of mission as a project, which is like an add-on part of the ministry, towards a mission as a calling, direction, identity and function of a congregation. This kind of mission should target transformation of the inner person so that transformation of all the congregational programs and social ministry could be effectively implemented.

\section{Inculturation of the gospel}

Bosch (2000:447) describes inculturation as translation of the Christian faith into a culture which ultimately leads to the manifestation of a pluriform character of Christian faith. In an African church the issue of inculturation of the Christian faith is a contested debate. Even in the DRCA OFS it has been indicated that there is a need of inculturation of the gospel to help clear the ambiguous standpoint the church has on some cultural practices. The church in Africa has fallen into a trap of uncritical acceptance of the church doctrines and practices from the mother church. This ended up by creating a dual spiritual life style and doing religious practises that are foreign to one's culture. The DRCA OFS seems to have fallen into this trap when it just accepted white missionaries' condemnation of some African practices as demonic and not providing an adequate alternative to appease a need to perform those condemned cultural practices. Therefore, there is a need to review the process and practice of the inculturation of the gospel within the DRCA OFS. According to Bosch (2000:452-454), this review could help with the reformulation and review of some local ministerial and cultural practices and contribute to an enriched plurality of theologies. Furthermore, it can contribute to enhance the self-esteem of indigenous practitioners because together with the Holy Spirit they will then be agents of change and improvement of the indigenous culture. Lastly, Bosch (2000:454) argues that inculturation is a double movement, that involves inculturation of Christianity and Christianisation of culture. Inculturation of Christianity means making the gospel something that can be used in culture whilst Christianisation of culture entails making use of already present cultural systems to give original expression of Christian life. This double movement of inculturation helps with the internalisation of the gospel within culture and makes it easy for the gospel to be embodied in some local cultural concepts and practices that could be used to perpetuate the Christian faith. In light of the above, for the DRCA OFS a review of the process of inculturation of the gospel could help with Christianisation of cultural practices like the traditional initiation schools. It will enrich and 
improve the confidence of its members as they will participate together with the Holy Spirit as agents of change of the indigenous culture and local context.

\section{Effective leadership}

There is a need for an effective leadership to implement the above suggested solutions in the declining ministry of the DRCA OFS. The type of leadership needed depends on the various factors which need to be considered. It must be noted that this section is still about the pragmatic task where Osmer (2008:176-178, 201) emphasises the role of leadership with its vision, analysis of the situation and implementing of the strategies. According to Osmer (2008:176-178, 194-197) there are three types of leadership styles that can be engaged in a congregation, task oriented, transactional and transforming ${ }^{17}$ leadership. Amongst the three, Osmer $(2008: 178,196)$ argues that the transformational leadership is mostly needed in the mainline churches because of their challenge of internal and external ministry. Osmer (2008:196) defines transformational leadership as leadership that leads to a deep change in identity, culture, operating procedures and mission. Does this mean that transformational leadership is appropriate leadership for the DRCA OFS as a mainline church which is faced with internal and external challenges of ministry? The answer is not easy as it needs in-depth discussion which is not possible in this article because of limited space. In contrast, Hendriks (2004:56) suggests a system sensitive leadership because it engages conflict, and diversity while understanding the situation. It challenges the status quo that promotes conflicts and mobilises towards transformation that focus on the Triune God. For the DRCA OFS to get out of its declining ministry leadership framework, it should have a proper vision and strategy. It is dependent on the DRCA OFS leadership which of the above suggested leadership frameworks it will choose and implement and I would suggest the choice of transformational leadership because of the continuing decline of the ministerial situation in the DRCA OFS.

Furthermore, in order to understand the depth and stage of the situation of the declining ministry in the DRCA OFS, the analysis of the phases of congregational change can be used as tool. Roxburgh (2000:31-46) states that there are five phases of congregational change. Firstly, it is the stability phase where there is an adherence to established routines, traditions, rituals and control measures. Secondly, is the discontinuity phase where the internal and external challenges increase pressure on the congregation to reform but the leadership decides to ignore the challenges and maintain the status quo. Thirdly, is the disembedding phase which involves the uprooting of deeply connected relationships, beliefs, practices and values. This stage is characterised by instability, power struggles, stress and conflicts. Management cannot solve problems and gospel

17.Various scholars such as Price (2003:68), Chakraborty and Chakraborty (2004:194) Ramphele (2008:295), and Osmer (2008:196) use transforming leadership, transformative leadership and transformational leadership to relate to leadership transformative leadership and transformational leadership to relate to leadership However, I prefer the concept of transformational leadership. values are no longer observed. Fourthly, is the transition phase where there is more instability and lack of control. The unwanted changes abound all over and the management is unable to bring about a change that is needed within the church. Fifthly and lastly, is the reformation phase which takes time and is a period of normalcy with the new structures, values and expectations. In all these phases, the DRCA OFS is shifting from the disembedding phase towards the transition phase. At the moment the relationships are declining amongst those in leadership, conflicts are increasing because of power struggles and now some ministers are undermining the authority of the present leadership, hence, some DRCA OFS assemblies are organised without the permission of the Moderamen and synodical funds and administrative documents from congregations are no longer submitted to the head office.

In summary, any effective leadership framework implemented in the DRCA OFS for it to achieve the desired divine goal, it must implement the mission of the Triune God, understand the needs of the followers, know the personality of a leader, assess the context and identify the tasks to be achieved (D'Souza 2001:168). An analysis of the situation in the ministry of the DRCA OFS was done whereby the DRCA OFS can be described as a black African mainline church struggling with internal and external ministry, as well as historical and contemporary challenges.

\section{Conclusion}

DRCA OFS is one of the mainline and African churches. It displays to a great extent many of the challenges that the African mainline and the mission churches have. The internal challenges of the DRCA OFS are leadership characterised by growing internal conflicts and declining ministry in relationship with God, fellow believers and knowledge of the Word. The external ministerial challenges are declining mission and diaconial ministry. Furthermore, growth towards independence, financial dependence, mission work and spiritual maturity were defined as historical challenges which now have culminated into contemporary challenges.

The DRCA OFS as a church in the post-apartheid era is also struggling with the legacy of white imperialism. Internally, this white imperialism was experienced from the racial mission policy by the DRC which encouraged the paternalistic approach by white missionaries to the mission churches and the segregation of churches based on race. The consequence of this racial mission policy in the DRCA OFS was a theological and financial dependence on the DRC FS. Externally, the DRCA OFS experienced white imperialism from the practice of colonialism, slavery and apartheid which exposed black Africans to the worst form of inhuman treatment. The consequence of this was psychological deprivation and low self-esteem mostly among the black Africans. In the DRCA OFS, the consequence was tension between DRCA members and the white missionaries from the DRC who were reluctant to give leadership to the black Africans. 
Therefore, in order to remedy the declining situation in the DRCA OFS, there is a need for a holistic solution. The first one is a need for a change, either an evolutionary or a radical transformation. The second remedy is an understanding of a missional mandate of the congregation as spiritual and societal engagement and mission as an identity not just an add-on to the congregational ministry. The third one is inculturation as a form of facilitating indigenisation of the gospel into culture and Christianisation of culture. Lastly, it is implementation of effective leadership. Effective leadership is not universal because it is influenced by various factors. However, transformational leadership and systems-sensitive leadership were suggested as some forms of leadership that can contribute to finding the solution in the declining ministry of the DRCA OFS although I propose the choice of transformational leadership. In conclusion, leadership is crucial to implement all these desired changes for the transformation of the ministry of the DRCA OFS. But this does not mean that leadership alone can make it, in order to succeed, the leadership needs to create an environment in which the Spirit is allowed to engage and guide the people of God towards the future and change planned by the Triune God.

\section{Acknowledgements Competing interests}

The author declares that he has no financial or personal relationships which may have inappropriately influenced him in writing this article.

\section{References}

Abah, A., 2012, 'Mobilising the African church for missions', in P. Vumisa (ed.), Evangelical Christian missions: An African perspective, pp. 91-116, Sun Press, Bloemfontein.

Bosch, D.J., 2000, Transforming mission, Orbis Books, New York.

Bouwers-Du Toit, N., 2010, 'Moving from development to social transformation Development in the context of mission', in I. Swart, H. Rocher, S. Green \& J. Erasmus (eds.), Religion and social development in post-apartheid South Africa: Perspectives for critical engagement, pp. 261-274, Sun Press, Stellenbosch.

Bragg, W.G., 1987, 'From development to transformation', in V. Samuel \& C. Sugden (eds.), The church in response to human need, pp. 20-47, W.B. Eerdmans, Oxford.

Buntu, B.A.O., 2013, 'Claiming self: The role of Afrikology in social transformation' Scriptura 112, 1-12. https://doi.org/10.7833/112-0-62

Chakraborty, S.K. \& Chakraborty, D., 2004, 'The transformed leader and spiritual psychology: A few insights', Journal of Organisational Change Management 17(2), 194-210. https://doi.org/10.1108/09534810410530610

Coetzee, M. \& Conradie, E., 2010, 'Apartheid as quasi-soteriology: The remaining lure and threat', Journal of Theology for Southern Africa 138, 112-123.

Crafford, D., 1982, Aan God die dank, NG Kerk-boekhandel, Pretoria.

Cronjé, J.M., 1982, Born to witness, N.G. Kerk Boekhandel Transvaal, Pretoria.

De Jong, A., 2001, 'Africans viewed in the missionary mirror', Exchange 30(1), 49. https://doi.org/10.1163/157254301X00048

DRCA General Synod, 2003a, Agenda of the DRCA General Synod, s.n., Kroonstad.

DRCA OFS, 1975, Agenda of the DRCA OFS Synod, s.n., Reitz.

DRCA OFS, 1995, Agenda of the DRCA OFS Synod, s.n., Parys.

DRCA OFS, 1999, Agenda of the DRCA OFS Synod, s.n., Thaba-Nchu.

DRCA OFS, 2003b, Church Order, s.n., Bloemfontein.

DRCA OFS, 2007, Agenda of the DRCA OFS Synod, s.n., Tseseng, Qwaqwa.

DRCA OFS, 2010, Agenda of the Synodical Commission of the DRCA OFS, s.n., Bloemfontein.

DRCA OFS, 2011, Agenda of the DRCA OFS Synod, s.n., Kroonstad.

DRCA OFS, 2015, Agenda of the DRCA OFS, s.n., Steynsrus.

DRCA OFS, 2017, Agenda of the DRCA Extra ordinary Synod, s.n., Virginia.

D'Souza, A.A., 2001, Leaders for today. Hope for tomorrow: Empowering and empowered leadership, Paulines Publications Africa, Nairobi.
Dubow, S., 2014, Apartheid 1948-1994, Oxford University Press, Oxford.

Du Preez, M., 2013, Rumour of spring: South Africa after 20 years of democracy, Zebra Press, Cape Town.

Duran, E., 2014, 'Foreword', in E.J.R. David (ed.), Internalized oppression: The psychology of marginalized groups, pp. xii-xvii, Springer Publishing Company, New York.

Du Toit, C., 2009, African challenges: Unfolding identities, Unisa Press, Pretoria.

Elphick, R., 2012, The equality of believers: Protestant missionaries and the racial politics of South Africa, University of Virginia Press, London.

Gordon, J.U., 2002, African leadership in the 20th century: An enduring experience in democracy, University Press of America, Lanham.

Guder, D.L., 2000, The continuing conversion of the church, W.B. Eerdmans, Grand Rapids, MI.

Gumede, W., 2012, Restless nation: Making sense of troubled times, NB Publishers, Cape Town.

Hendriks, H.J., 2004, Studying congregations in Africa, Paarl Print, Paarl.

Hunter, K.R., 1989, 'The quality side of church growth', in C.P. Wagner (ed.), Church growth: State of the Art, pp. 119-126, House Publishers, Wheaton.

Kalu, O.U., 2006, 'African Christianity from the world wars to decolonisation', in H. Mcleod (ed.), The Cambridge history of Christianity: World Christianities, pp. 197218, Cambridge University Press, Cambridge.

Kane, J.H., 1978, Understanding Christian mission, rev. edn., Baker Book House, Grand Rapids, MI.

Karolo e nkilweng ke ditho tsa kereke ya N.G. tse ntsho, 1987, Thuto ya Bokreste, p. 189, NGK Sending Uitgewers, Bloemfontein.

Kekana, N.F., 2012, 'A biblical theology of missions', in P. Vumisa (ed.), Evangelical Christian Missions. An African perspectives, pp. 69-90, Sun Press, Bloemfontein.

Kgatla, T. \& Magwira, A., 2015, 'The defining moments for the DRC mission policy of 1935 and 1947', Missionalia 43(3), 365-383.

Khauoe, M.J., 2011, The awakening giant: The African church and its calling to mission, CLF, Wellington.

Kritzinger, J.J., 2011, 'Die einde van sending: Fases in die sending bedryf', Acta Theologica 31(2), 111-134. https://doi.org/10.4314/actat.v31i2.6

Kritzinger, K., 2013, 'The role of the DRC and DRCA in the struggle for justice in South Africa 1986-1990', This is a revised version of a paper presented to the conference
entitled The Reformed Churches in South Africa and the Struggle for Justice, entitled The Reformed Churches in South Africa and the Struggle for Justice, Remembering 1960-1990, hosted by the Faculty of Theology, Stellenbosch
University, 14-16 May 2012, viewed 25 September 2017, from http://www.scielo. University, 14-16 May 2012, vi
org.za/pdf/she/v39n2/12.pdf

Lartey, E.Y., 2013, Postcolonising God: An African practical theology, SCM Press, London.

Lebone, M., 2002, 'Die totstandkoming van die Nednederduitse Gereformeerde Kerk in Afrika: Hoogtepunte en laagte punte van die afgelope vyftig jaar', in P. Coertzen, (ed.), 350 jaar: Gereformeerd 1652-2002, pp. 277-278, CLF, Wellington.

Lubbe, J.J., 2001, 'A tale of fear and faith', in J.W. Hofmeyer, C.J.S. Lombaard \& P.J. Maritz (eds.), 1948 plus 50 years: Theology, apartheid and church past, present and future, perspectives on Christianity, pp. 1-50, IMER Publishers, Pretoria. (Series 5, vol. 5).

Masuku, T.M., 2014, 'Prophetic mission of faith communities in South Africa', Missionalia 42(3), 151-167.

Mbigi, L. \& Maree, J., 1995, Ubuntu: The spirit of African transformation management Knowledge Resources, Randburg.

Mohlamme, J.N. \& Qakisa, B.E., 1992, 'Elders in the Dutch Reformed Church in Africa', in L. Vischer (ed.), The ministry of elders in the Reformed church, pp. 231-241, Swiss Federation of Protestant Churches, Berne.

NG Kerk in Afrika (NGKA), s.a., viewed 28 January 2016 from www.ngka.co.za/ngka.

Nimako, K. \& Willemsen, G., 2011, The Dutch Atlantic slavery, abolition and emancipation, Pluto Press, London.

Odendaal, A.A., 1956, Litaba tsa Kereke ea Ned, Geref.N.G. Sendingpers, [s.I.].

Odendaal, A.A., 1970, 'Die Nederduitse Gereformeerde Sending in die Oranje-Vrystaat (1842-1910)', DTh., Universiteit van Stellenbosch, Stellenbosch.

Osmer, R., 2008, Practical theology, an introduction, W.B. Eerdmans, Cambridge.

Pali, K.J., 2016, Leadership and transformation in the African church: A practical theological study of one denomination, A joint D. Phil. thesis, University of the Free State, Bloemfontein \& Vrije Universiteit, Amsterdam.

Pali, K.J. \& Verster, P., 2013, 'The Church and mission: Challenges and perspectives from DRCA in the Free State', Journal for Christian Scholarship 49(3), 227-255.

Phadimeho kgahlanong le ditlwaelo tsa bohedene, 1987, in Thuto ya Bokreste, pp. 204-207, NGK Sending Uitgewers, Bloemfontein.

Price, T.L., 2003, 'The ethics of authentic transformational leadership', Leadership Quarterly 14 (1), 67-81. https://doi.org/10.1016/S1048-9843(02)00187-X

Ramphele, M., 2008, Laying ghosts to rest - Dilemmas of the transformation in South Africa, Tafelberg, Cape Town.

Roxburgh, A., 2000, Crossing the bridge: Church leadership in times of change, Percept Group, viewed 30 August 2017, from www.percetnet.com

Roxburgh, A.J. \& Romanuk, F., 2006, The missional leader, Jossey-Bass, San Francisco, CA.

Saayman, W., 1991, Christian mission in South Africa, Unisa Press, Pretoria. 
Sandford, J. \& Sandford, P., 1982, The transformation of the inner man: The most comprehensive book on inner healing today, Victory, Tulsa, OK.

Schoeman, K., 2015, 'Describing a congregation: Looking for certain markers', in M. $\mathrm{Nel}$ (ed.), Identity-driven churches: Who are we, and where are we going? pp. 363-371, Biblecor, Wellington.

Shawchuck, N. \& Heuser, R., 1993, Leading the congregations: Caring for yourself while serving others, Abingdon Press, Nashville, TN.

URCSA General Synod, 1994. Acts of the inauguration of the first general synod of URCSA, s.n., Belhar.
Van der Walt, B.J., 2003, Understanding and rebuilding Africa. From desperation today expectation for tomorrow, ICCA, Potchefstroom.

Van der Watt, G., 2010, 'Recent developments and challenges in understanding the Dutch Reformed family of Churches' missional identity and calling', Nederduitse Gereformeerde Teologiese Tydskrif 51(3), 1-13.

Vumisa, P., 2012, 'African Missionary', in P. Vumisa (ed.), Evangelical Christian missions. An African perspective, pp. 117-138, Sun Press, Bloemfontein

Young, J.M.L., 2007, Missions: The biblical motive and aim, Crown and Covenant Publications, Pittsburgh. 